\title{
Survivorship of species caught in a longline tuna fishery in the western equatorial Atlantic Ocean
}

\author{
Diogo M. Nunes ${ }^{1}$, Fabio H.V. Hazin ${ }^{2}$, Ilka S.L. Branco-Nunes ${ }^{2}$, Humberto Hazin ${ }^{3}$ \\ José Carlos Pacheco ${ }^{1}$, Andre S. Afonso ${ }^{2}$, Bruno L. Mourato ${ }^{4}$ \& Felipe C. Carvalho ${ }^{5,6}$ \\ ${ }^{1}$ Unidade Acadêmica de Serra Talhada, Universidade Federal Rural de Pernambuco \\ Serra Talhada, Pernambuco, Brazil \\ ${ }^{2}$ Departamento de Pesca, Universidade Federal Rural de Pernambuco, Recife, Brazil \\ ${ }^{3}$ Departamento de Ciências Animais, Universidade Federal Rural do Semiárido, Mossoró, Brazil \\ ${ }^{4}$ Instituto del Mar, Universidade Federal de São Paulo, Santos, São Paulo, Brazil \\ ${ }^{5}$ NOAA, Servicio Nacional de Pesca Marina, Islas del Pacífico Fisheries Science Center, Honolulu, EE.UU. \\ ${ }^{6}$ University of Hawaii, Joint Institute for Marine and Atmospheric Research, Honolulu, USA \\ Corresponding author: Diogo M. Nunes (diogoidnunes@gmail.com)
}

\begin{abstract}
Longlines bearing "hook timers" (HTs) and alternating circle (15/0 and 17/0) and "J" (10/0) hooks were employed off the coast of Brazil to measure differences in fishing mortality associated with hook type and on-hook time between capture and boarding. A total of 431 HTs were activated, revealing a clear pattern of the increased mortality rate of fishes associated with increased on-hook time. Swordfish had high mortality rates, unlike blue sharks, which had low mortality rates regardless of hook type and the location in which the hook was transfixed. The six species of tunas and billfishes examined in this study showed a strong association between hooking location and the animal's release condition, with reduced mortality associated with individuals hooked externally. Results suggest that knowledge of factors affecting the survival of pelagic fishes caught in longline fisheries may enable the development and adoption of fishing methods to reduce mortality of longline bycatch.
\end{abstract}

Keywords: mortality; circle hooks; pelagic longline; hook timer; bycatch; hooking location

\section{INTRODUCTION}

Commercial pelagic tuna longline fishing has been conducted in Brazil since 1956, when Japanese longliners were chartered by a Brazilian company based in Recife, Pernambuco (Hazin et al., 1998). The first Brazilian longline vessels targeted tuna (Thunnus spp. South, 1845) using a multifilament longline (Hazin et al., 2002). In 1994, part of the longline fleet based in São Paulo began targeting swordfish (Xiphias gladius Linnaeus, 1758) using monofilament longlines baited with squid and chemical light sticks (Amorim et al., 2002).

Since 1997, the Brazilian longline fleet has targeted swordfish, bigeye tuna (Thunnus obesus Lowe, 1839) and yellowfin tuna (T. albacares Bonnaterre, 1788), while all other species are considered incidental catch (retained non-target species) or bycatch (discarded nontarget species). The catch of non-target species has gained increasing prominence internationally due to fishing impacts on their populations, particularly for those groups with long life cycles and low reproductive rates such as elasmobranchs, sea mammals and sea turtles (Lewison et al., 2004). In some cases, the effects of longline fisheries may impact potential recovery for already depleted species, such as loggerhead (Caretta caretta Linnaeus, 1758) and leatherback sea turtles (Dermochelys coriacea Vandelli, 1761) (Watson et al., 2005), as well as white marlin (Kajikia albida Poye, 1860) and blue marlin (Makaira nigricans Lacepède, 1802) (Diaz, 2008).

Corresponding editor: Patricio Arana 
The International Commission for the Conservation of Atlantic Tunas (ICCAT) is the Regional Fishery Management Organization (RFMO) responsible for the conservation of tunas and tuna-like species in the Atlantic Ocean, including elasmobranchs, as well as migratory teleost species such as the swordfish and billfishes. Currently, dead discard estimates incorporated or not into ICCAT assessments but may substantially increase estimates of fishing mortality and consequently change perspectives of population health for some species, particularly in the case of incidental and bycatch species.

Circle hooks (a hook with the point turned perpendicularly back to the shank) may be used to reduce fishing mortality (Serafy et al., 2012). Recent studies have shown that circle hooks with no offset or a minor offset (about $4^{\circ}$ ) cause less physical damage to fish than J-hooks (Reinhardt et al., 2017), because of the tendency of circle hooks to engage fish in the mouth rather than in the pharynx, esophagus or stomach, therefore increasing rates of post-release survival (e.g., Kerstetter \& Graves, 2006). In contrast to J-hooks, circle hooks tend to slide over soft tissue and rotate as the eye of the hook exits the mouth, frequently resulting in the hook catching in the jaw (Cooke \& Suski, 2004). In parallel, the Pacheco et al. (2011) study on the use of circle and J-hooks, in the western equatorial Atlantic Ocean, found that the catch rates for target species were higher using circle hooks for tunas, and some target incidental and bycatch species caught on circle hooks had higher rates of survival at haulback than those caught on J-hooks.

The fact that some fisheries typically use long soak times (the period between deployment and retrieval, when the gear is actively fishing) also compromises the quality in species of commercial value (Pacheco et al., 2011), and the post-release survivorship in bycatch, such as white and blue marlin, or incidentally caught species (Kerstetter \& Graves, 2006). The boarding of white and blue marlins that are still alive the time of at haulback (gear retrieval) is prohibited by Brazilian law to reduce mortality in non-target species. Of these cases, increasing both post-capture and post-release survivorship becomes particularly important for the conservation of bycatch species.

However, each species is unique in its ability to endure fisheries capture based on its physiological and life history characteristics (Brooks et al., 2012; Marshall et al., 2012; Skomal \& Mandelman, 2012). For example, many carcharhinid requiem and sphyrnid hammerhead sharks are ram ventilators, requiring constant movement to force oxygenated water over the gills (Carlson et al., 2004). Ram ventilators must either increase swimming speeds and gape of their mouths to compensate for decreased oxygen availability (Carlson $\&$ Parsons, 2001), which is difficult while hooked on a longline. The size of the shark also influences at-vessel mortality rates in some species (Davis, 2002; Morgan $\&$ Burgess, 2007). Other environmental factors also affect a species' ability to survive fishing operations, including water temperature, with higher temperatures having a negative effect on the sharks' survival (Manire et al., 2001; Braccini et al., 2012; Hoffmayer et al., 2012) and leading to acidosis (Heisler, 1988).

In this context, the use and improvement of sustainable and alternative fishing techniques enabling the reduction of captures and mortality of incidental and bycatch species in commercial longline fisheries capture, based on a better understanding of the interaction of fish with the fishing gear, are of great importance due to their potential contribution to the conservation of these species. Alternative fishing techniques may include the use of circle hooks rather than traditional J-hooks (Pacheco et al., 2011) or changes in fishing gear (Afonso et al., 2012). The present study investigated the variables that potentially affected post-capture survival of animals from the Brazilian commercial pelagic longline fishery operating in the western equatorial Atlantic Ocean.

\section{MATERIALS AND METHODS}

\section{Experimental design}

Longlines consisted of the mainline of approximately 90 $\mathrm{km}$ of $3.5 \mathrm{~mm}$ monofilament (polyamide), with eight radio-buoys distributed along the mainline. The longline was truncated into sections consisting of a surface marker buoy followed by four or five bullet-buoys attached with approximately $16 \mathrm{~m}$ of $2.0 \mathrm{~mm}$ monofilament (polyamide) buoy lines. Gangions were composed of a "snap" or tuna clip, an $18 \mathrm{~m}$ section of $2.0 \mathrm{~mm}$ diameter nylon monofilament line with a $75 \mathrm{~g}$ swivel, another $2.0 \mathrm{~m}$ section of $2.0 \mathrm{~mm}$ thick nylon monofilament, and a fish hook. Once the fishing area was selected, operations began with the setting of the longline, always in the late afternoon (between 14:00 and 16:00 h). Haulback, in turn, always started at the beginning of each morning (between 03:00 and 05:00 h). Bait always consisted of squid (Illex sp. Steenstrup, 1880) in conjunction with a battery-operated light attractor (Electralume ${ }^{\circledR}$ LED light Lindgren-Pitman Inc., Pompano Beach, Florida, USA).

Longline survival rates for every species caught were compared across several factors including hook type, time in the hook and fish. Three types of hook were used, namely $15 / 0,5^{\circ}$ offset ( 25 sets; MustadBrazil \#39965) and $17 / 0,5^{\circ}$ offset (28 sets; MustadBrazil \#39965) circle hooks which were compared with the traditional 10/0, $5^{\circ}$ offset, J-hook (MustadBrazil \#4480). 
"Hook timers" (HTs Lindgren-Pitman Inc., model HT600, Pompano Beach, Florida, USA) were fitted to the secondary lines to identify the time that fish remained alive on the line after capture, as well as the exact time they were caught. Hook timers consisted of a digital clock surrounded by a hard plastic waterproof case $(600 \mathrm{~m}$ durable depth), which is activated by a magnet when a fish is hooked. When HTs were brought to the surface, the time recorded on the clock, representing the time elapsed since the capture of the animal, was registered. The HTs do not record the capture time, record the time elapsed since capture. Only by subtracting this elapsed time from capture with the time of haulback we have the capture time.

\section{Data collection}

From May 2009 to January 2010, four cruises were conducted aboard one Brazilian vessel, which operated with pelagic longline in the equatorial Atlantic Ocean. Fifty-three sets were made between $05^{\circ} \mathrm{N}$ to $02^{\circ} \mathrm{S}$ and $28^{\circ}$ to $38^{\circ} \mathrm{W}$ (Fig. 1). Overall, 7,800 hooks combined with HTs were deployed during the experiment, yielding an average of 147 HTs per set.

All specimens caught were identified and had the individual health status determined immediately after boarding. A specimen was conservatively considered dead if it did not show any signs of activity in the water or on the deck, following Falterman \& Graves (2002) and Afonso et al. (2011). It implies that moribund fish which would most likely die but were still alive by the time of haulback were not considered dead, thus precluding mortality overestimation. Morphometric measurements were also recorded for all specimens caught, with fork length (FL) or total length (TL) being taken for elasmobranchs and most teleosts and lower jawfork length (LJFL) being taken for swordfish (Xiphias gladius) and istiophorid billfishes. Also, hook type and hook's attachment location on the fish (external = mouth corner or jaw and nose/bill area $v s$. internal $=$ gills, esophagus or stomach) were recorded according to Kerstetter \& Graves (2006). The periods of dusk and dawn were determined using the NOAA Earth System Research Laboratory website (NOAA, 2019).

\section{Statistical analysis}

Mortality rates were interpreted as the proportion of individuals that were dead at the time of haulback. Differences in mortality rates by hook location and by hook type were assessed using Chi-square tests. The analyses were conducted at species-level and also at higher taxonomic levels involving groups of species. Groups included tunas of the genus Thunnus (bigeye tuna T. obesus, yellowfin tuna T. albacares and albaco-

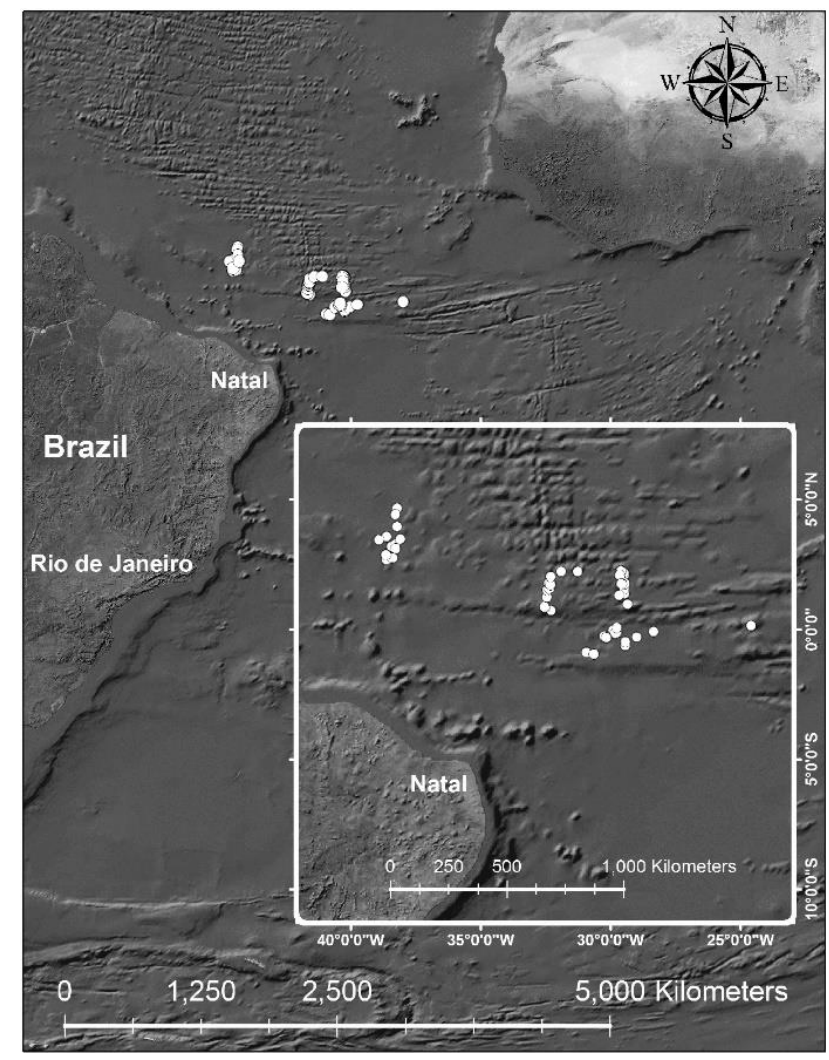

Figure 1. Study area in the western equatorial Atlantic Ocean, where 53 longline sets were carried out for the experiments, from May 2009 to January 2010.

re tuna, T. alalunga Bonnaterre, 1788); istiophorid billfishes (white marlin, blue marlin and sailfish, Istiophorus platypterus Shaw, 1792); sharks, rays, turtles and all other teleost fishes (not including the tunas, swordfish and the billfishes). Information on mortality is not available for other sharks and other teleost fishes. Additionally, the fishing sets were not included in the analysis as a factor because the whole experiment was performed in the same fishing area with the same vessel and crew.

Shapiro-Wilk normality tests were initially applied to measure differences in mortality rate between individual lengths (in $\mathrm{cm}$ ) and on-hook time (time elapsed between hooking and boarding, in hours) for species and species groups. Bartlett tests for homogeneity of variances and a test to compare means ( $t$-test for values meeting the assumptions of normality and homoscedasticity and "Wilcoxon" for the other cases) followed. All analyses were performed using the $\mathrm{R}$ statistical program (R Development Core Team, 2007), with all results being considered statistically significant at $95 \%(P=0.05)$. 


\section{RESULTS}

During the study, 1,783 fish (23 species) and 65 turtles (two species) were caught with a total effort of 37,100 hooks (18,550 traditional J-hooks and 18,550 circle hooks). Target species (swordfish (Xiphias gladius), bigeye tuna Thunnus obesus and yellowfin tuna Thunnus albacares) totaled more than $65 \%$ of all fish caught (Table 1).

\section{Mortality by hook type and hook location}

The 15/0 circle hooks resulted in the lowest mortality rates $(41.2 \%)$ for all species together, followed by the traditional J-hook (55.4\%) and the 17/0 circle hooks (55.2\%), although the difference was not statistically significant $\left(\chi^{2}=1.381, \mathrm{df}=2, P=0.501\right)$. Some species such as swordfish, albacore tuna Thunnus alalunga and wahoo showed relatively high mortality rates regardless of hook type used, while others, such as common dolphinfish (Coryphaena hippurus) and blue sharks (Prionace glauca) showed lowest mortality rates (Table 1), though differences within species among hook types were not statistically significant.

Bigeye tuna showed lower levels of mortality with 15/0 circle hooks, without significant differences among hook types, unlike yellowfin tuna, which showed a significant reduction in mortality rates when using 17/0 circle hooks $\left(\chi^{2}=11.356, \mathrm{df}=2, P=0.003\right)$. Billfishes and crocodile sharks (Pseudocarcharias kamoharai) had significantly lower mortality rates on 17/0 circle hooks as compared to J-hooks $\left(\chi^{2}=9.406\right.$, $\left.\mathrm{df}=2, P=0.009 ; \chi^{2}=5.081, \mathrm{df}=2, P=0.025\right)$. For mako shark (Isurus sp.) and oceanic whitetip shark (Carcharhinus longimanus), mortality rates were significantly lower on $15 / 0$ circle hooks $\left(\chi^{2}=8.261\right.$, df $=2, P=0.016 ; \chi^{2}=8.833$, df $=2, P=0.012$, respectively). The ray group had higher mortality rates when caught on 17/0 circle hooks $\left(\chi^{2}=13\right.$, df $=2, P=$ 0.001 ), while sea turtles had the highest mortality rates when caught on traditional J-hooks, without significant differences $\left(\chi^{2}=1.447, \mathrm{df}=2, P=0.485\right)$. All other species analyzed showed no statistical difference in mortality rate by hook type.

The hooking position varied between hook types (grouped circle vs. traditional J-hooks) and between species groups (Fig. 2a). All species groups, except for the group of other teleost fishes and sea turtles, had significantly higher internal hooking values on the Jhooks compared to circle hooks (tunas $P<0.001$; swordfish $P=0.024$; billfishes $P=0.011$; sharks $P=$ 0.037 ; and rays $P<0.001$ ).

Swordfish showed a high mortality rate regardless of hook type and hooking position, while the blue shark showed lower mortality rates regardless of hook type and hooking position. By contrast, all species of tunas and billfishes showed a significant trend toward reduced mortality in individuals hooked externally, with a significant relationship observed between hooking position and the animal's condition (alive or dead) $\left(\chi^{2}=13.54, P<0.001\right)$ (Fig. 2b).

\section{Individual length}

For target species, a trend of increased survival with increasing individual fish length was observed, although this difference was only statistically significant for yellowfin tuna and swordfish (Table 2). In the shark's group, this trend was only observed for the blue shark with a significant difference. All other shark species showed the opposite pattern; however, the difference was only statistically significant for the crocodile shark. Similarly, higher mortality for larger specimens was observed for the common dolphinfish, escolar and "other teleost," but these trends were also not statistically significant.

\section{Time elapsed between hooking and boarding}

A total of 431 HTs were activated and retrieved with fish on the line, representing 23 species, of which 13 were caught more frequently at night. Only the ocean sunfish, pelagic stingray, and billfish and sea turtle groups did not show a clear pattern of preference between day and night (Fig. 3).

Of all the HT-documented catches, $8 \%$ were activated during haulback (04:00 to 14:00 h), 9\% during the device drift (23:00 to 03:00 h), with the majority $(83 \%)$ being hooked during release of the longline, i.e., during the evening and night between 18:00 and 24:00 h (Fig. 4). There was a definite increase in the mortality rate as a result of increased time elapsed between hooking and boarding, although some species endured long periods of capture and were generally alive by the time of boarding. Bigeye tunas, yellowfin tunas, and blue sharks, for instance, survived on the longline gear for extended periods ( $14 \mathrm{~h}$ ), which was the longest time on-hook recorded in this study (between 11 and $14 \mathrm{~h}$ ).

Six species, namely the billfishes, tunas, swordfish, and wahoo, showed significant differences in at-vessel health condition as related to on-hook time, revealing that a reduction in on-hook time may influence the survival of these species (Table 3 ).

All sea turtles caught on lines with activated HTs were alive at the time of boarding $(n=6)$, resulting in live releases. However, the estimated time on the line and capture time were affected by this group's behavior and the low weight of some species (e.g., Alepisaurus sp., E. bipinnulata, $P$. violacea), triggering HTs only moments before boarding when the line was tensioned 
Table 1. Catch composition and proportion of mortality in experiments in the equatorial western Atlantic Ocean. Rays ${ }^{1}$ : pelagic stingray Pteroplatytrygon violacea (Bonaparte, 1832) $(\mathrm{n}=53)$, and manta ray Manta sp. (Bancroft, 1829) $(\mathrm{n}=29)$. Turtles²: Olive Ridley Lepidochelys olivacea (Eschscholtz, 1829) $(\mathrm{n}=40)$, leatherback Dermochelys coriacea (Vandelli, 1761) $(\mathrm{n}=12)$, and unidentified $(\mathrm{n}=13)$. Other sharks ${ }^{3}$ : hammerheads Sphyrna sp. Rafinesque, $1810(\mathrm{n}=6)$, threshers Alopias spp. Rafinesque, $1810(\mathrm{n}=4)$ and silky sharks Carcharhinus falciformis (Müller \& Henle, 1839) $(\mathrm{n}=3)$. Other teleost fishes: ocean sunfish Mola mola (Linnaeus, 1758) $(\mathrm{n}=6)$, oilfish Ruvettus pretiosus Cocco, $1833(\mathrm{n}=3)$ and rainbow runner Elagatis bipinnulata (Quoy \& Gaimard, 1825) ( $\mathrm{n}=1)$. (-) Information on mortality is not available.

\begin{tabular}{|c|c|c|c|c|c|c|}
\hline \multirow{2}{*}{ Scientific name } & \multirow{2}{*}{ Common name } & \multicolumn{2}{|c|}{ Catch composition } & \multicolumn{3}{|c|}{ Percent mortality } \\
\hline & & $\%$ & $\mathrm{n}$ & C $15 / 0$ & C $17 / 0$ & J $10 / 0$ \\
\hline Xiphias gladius Linnaeus, 1758 & Swordfish & 30.9 & 571 & 80.0 & 90.4 & 87.3 \\
\hline Thunnus obesus (Lowe, 1839) & Bigeye tuna & 25.5 & 472 & 39.3 & 47.8 & 41.5 \\
\hline Prionace glauca (Linnaeus, 1758) & Blue shark & 14.7 & 272 & 11.6 & 21.3 & 13.8 \\
\hline Thunnus albacares (Bonnaterre, 1788) & Yellowfin tuna & 9.1 & 169 & 71.4 & 46.1 & 70.3 \\
\hline Rays $^{1}$ & & 4.4 & 82 & 0.0 & 6.5 & 0.0 \\
\hline Turtles $^{2}$ & & 3.5 & 65 & 0.0 & 0.0 & 11.8 \\
\hline Coryphaena hippurus Linnaeus, 1758 & Common dolphinfish & 1.6 & 29 & 0.0 & 30.8 & 20.0 \\
\hline Thunnus alalunga (Bonnaterre, 1788) & Albacore tuna & 1.3 & 24 & 100.0 & 88.9 & 92.9 \\
\hline Pseudocarcharias kamoharai (Matsubara, 1936) & Crocodile shark & 1.2 & 23 & - & 22.2 & 40.0 \\
\hline Kajikia albida (Poey, 1860) & White marlin & 1.0 & 19 & 33.3 & 16.7 & 90.0 \\
\hline Alepisaurus sp. Lowe, 1833 & Lancetfish & 1.0 & 18 & 100.0 & 100.0 & 83.3 \\
\hline Isurus sp. Rafinesque, 1810 & Mako shark & 0.9 & 17 & 25.0 & 50.0 & 40.0 \\
\hline Lepidocybium flavobrunneum (Smith, 1843) & Escolar & 0.9 & 16 & 25.0 & 50.0 & 37.5 \\
\hline Carcharhinus longimanus (Poey, 1861) & Oceanic whitetip & 0.8 & 15 & 33.3 & 50.0 & 62.5 \\
\hline Acanthocybium solandri (Cuvier, 1832) & Wahoo & 0.8 & 14 & 100.0 & 75.0 & 100.0 \\
\hline Other sharks ${ }^{3}$ & & 0.7 & 13 & - & - & - \\
\hline Istiophorus albicans (Latreille, 1804) & Atlantic sailfish & 0.5 & 10 & 0.0 & 20.0 & 50.0 \\
\hline Other teleost fishes & & 0.5 & 10 & - & - & - \\
\hline Makaira nigricans Lacepède, 1802 & Blue marlin & 0.5 & 9 & 0.0 & 33.3 & 60.0 \\
\hline Total & & & 1848 & 40.9 & 57.0 & 55.4 \\
\hline
\end{tabular}

(12 $\min$ on average). The exception was one leatherback turtle that was on the line six hours before being released alive. Like sea turtles, all catches $(n=$ 10 ) in the ray group were alive. Unlike sea turtles, however, except for three rays that triggered the HT only moments before being boarded, all the other rays triggered HTs at much earlier times of capture (on average $390 \mathrm{~min}$ ).

As for bait condition in lines holding activated HTs but with no hooked organism on the ganglion, $37 \%$ had no bait remaining, $38 \%$ had half of the bait remaining and $14 \%$ were missing the bait and hook. Only $11 \%$ of hooks without hooked fishes had the bait still intact.

\section{DISCUSSION}

Increases in survival rates of species caught on circle hooks, compared to traditional J-hooks employed in pelagic longline fishing, owing to the higher probability of the latter to hook fish internally, causing more severe injuries-, have been widely documented (Kerstetter \& Graves, 2006; Yokota et al., 2006; Kerstetter et al., 2007; Ward et al., 2009; Pacheco et al., 2011). Morta- lity rates in this study confirm already observed trends from the same region of the Atlantic (Kerstetter et al., 2007; Pacheco et al., 2011), with swordfish (Xiphias gladius) and marlins having high mortality values, unlike rays, sea turtles, blue sharks (Prionace glauca) and dolphinfishes, that showed reduced mortality rates regardless of hook type. All species of billfishes and sea turtles, as well as the crocodile shark (Pseudocarcharias kamoharai), exhibited lower mortality rates on circle hooks, increasing the chances of releasing these animals alive (Sales et al., 2010). These results are particularly relevant in the case of white marlin (Kajikia albida) and blue marlin (Makaira nigricans), due to the mandatory release of these species if they are alive at longline haulback, required by Brazilian law, in response to management recommendations adopted by ICCAT. The results presented here indicate that the use of circle hooks by the Brazilian pelagic longline fleet may not only increase the likelihood of releasing incidentally-caught species alive, making longlines less intrusive from a conservation point of view, but also increase the quality and subsequent value of landed fishes. 

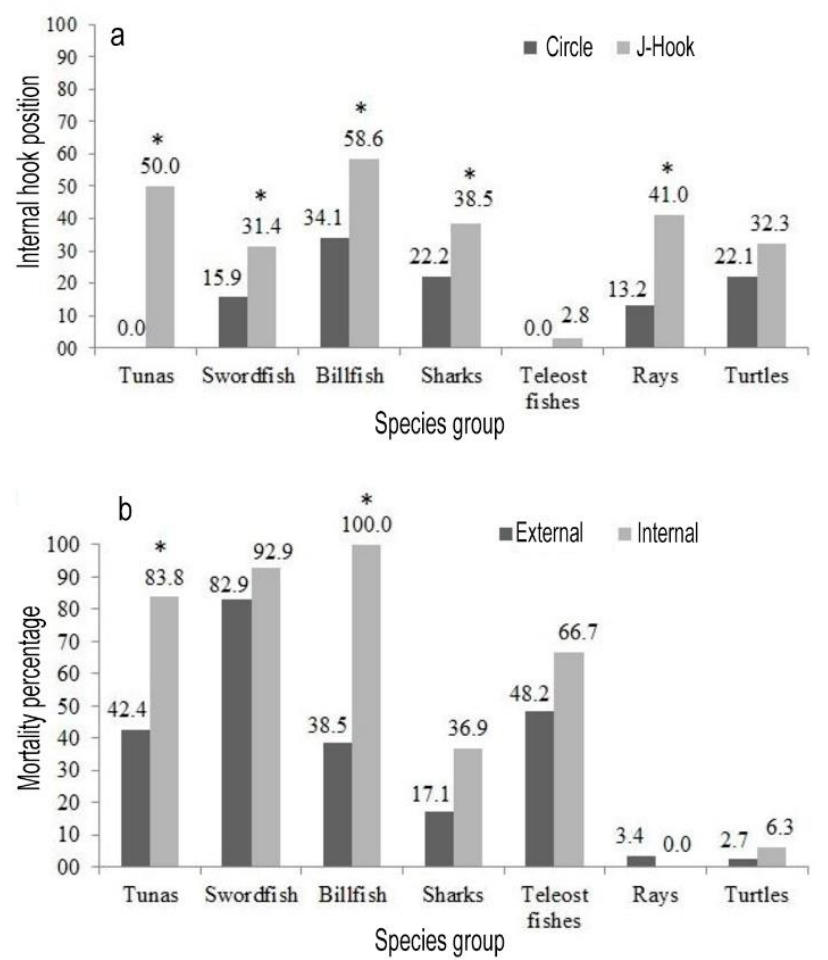

Figure 2. a) Proportion of individuals captured internally per-hook type, and b) mortality rate according to the hook position, for groups of species caught on longlines in the equatorial western Atlantic Ocean (*Results were statistically significant differences).

Studies have shown that hooking location is one of the most critical factors affecting fish (Cooke \& Suski, 2004; Kerstetter \& Graves, 2006) and sea turtle (Watson et al., 2005) survival. The tendency for circle hooks to fix internally less often than traditional Jhooks is reflected in the lower mortality rates obtained by them. The higher percentage of external fixation (corner of the mouth or jaw) achieved by circle hooks is the result of the hook tip being perpendicular to the shaft in circle hooks, allowing it to slide through the throat without piercing the digestive tract as it is the norm with traditional J-hooks (Cooke \& Suski, 2004). Both trends were observed in this study, with circle hooks having higher rates of external fixation and internally hooked individuals having higher mortality rates.

Numerous studies that have evaluated the effect of individual fish length concerning mortality at the time of boarding have obtained varying results by species tested. For example, this study and others researches indicated that post-capture/at-haulback mortality of blue sharks declined with individual length (Moyes et al., 2006; Campana et al., 2009; Coelho et al., 2013), a pattern also described for other sharks (Morgan \& Carlson, 2010) and teleosts (Neilson et al., 1989; Milliken et al., 1999).
Table 2. Mean individual lengths at the time of boarding and probability of changing survival rate between fish length and time since the capture of the main species captured in longline fishing operations in the equatorial western Atlantic Ocean. *Statistically significant $(\alpha=$ 0.05 ). **A negative value indicates a decrease in survival with increasing fish length.

\begin{tabular}{|c|c|c|c|c|c|}
\hline \multirow{2}{*}{ Species } & \multicolumn{2}{|c|}{$\begin{array}{c}\text { Average length } \\
(\mathrm{cm})\end{array}$} & \multicolumn{3}{|c|}{ Statistical analyses } \\
\hline & Live & Dead & Wilcoxon & $t$-test $* *$ & $P$-value \\
\hline Bigeye tuna & 128.5 & 125.7 & - & 1.3768 & 0.169 \\
\hline Yellowfin tuna & 148.8 & 137.1 & 3913.5 & - & $0.007 *$ \\
\hline Swordfish & 147.3 & 137.3 & - & 2.8615 & $0.005 *$ \\
\hline Blue shark & 234.5 & 224.1 & - & 2.0553 & $0.045^{*}$ \\
\hline Crocodile shark & 88.1 & 120.8 & - & -3.4623 & $0.010 *$ \\
\hline Common dolphinfish & 102.1 & 104.0 & 48 & - & 0.483 \\
\hline Escolar & 105.2 & 114.7 & - & -0.675 & 0.521 \\
\hline
\end{tabular}

In contrast, studies on freshwater trout (Taylor \& White, 1992) and bass (Malchoff \& Macneill, 1995), using rod and reel fishing, demonstrated that mortality rates were higher for larger individuals, similarly to the crocodile shark, common dolphinfish (Coryphaena hippurus), and escolar (Lepidocybium flavobrunneum) in this study, although only the first showed a statistically significant difference in mortality rates.

In a study performed in the east coast of the United States with 599 HTs triggered by 23 different species, $99 \%$ of swordfish, $100 \%$ of bigeye tuna Thunnus obesus, $85 \%$ of blue shark, and $96 \%$ of escolars were caught at night, while the yellowfin tuna (Thunnus albacares) did not show a clear preference between day (57\%) and night (43\%) and the dolphinfish showed a preference for the day (95\%) (Kerstetter \& Graves, 2006). Although a direct comparison with the present study is not entirely possible, since the longline was set between 14:00 and 16:00 $\mathrm{h}$ and retrieved from 03:00 to 05:00 $\mathrm{h}$, the time-of-hooking data obtained in the present study, with most of the catches have occurred from 18:00 to 24:00 h, seems to confirm this behavior, differing only in the case of dolphinfish. This apparent trend of higher catches during the night probably reflects the circadian behavior of most pelagic species (Dagorn et al., 2000; Weng et al., 2009), whose vertical migrations usually follow the movement of plankton, resulting in fishes being found near the surface at dusk and in deeper layers during the day. The higher catch rates observed during the early immersion time of the longline may also be a result of a higher attractive power of the bait, associated with its sinking movement. However, Boggs (1992) reported high percentages of animals caught during the drift or haulback phase when conducting experiments over shallow $(100 \mathrm{~m})$ and deep (200 to $400 \mathrm{~m})$ waters. Haulback operations in the study above occurred mainly in the afternoon, extending to $22: 00 \mathrm{~h}$, sugges- 


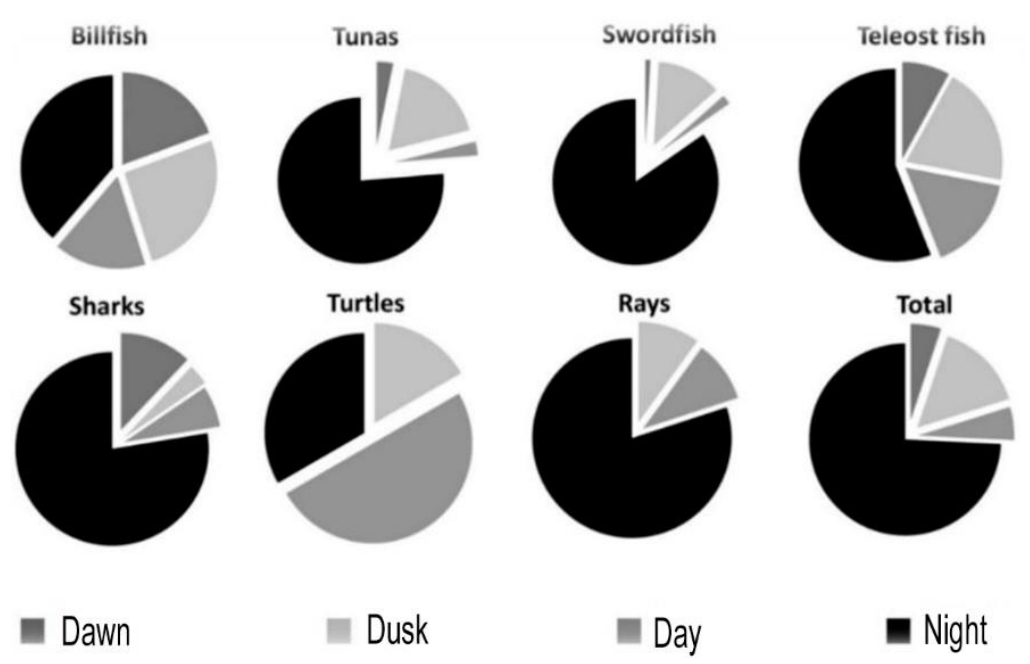

Figure 3. The proportion of individuals captured at different times of the day (dawn [between 04:00 and 05:00 h]; dusk [between 17:00 and 18:00 h]; day [between 05:00 and 17:00]; night [between 18:00 and 04:00]).

Table 3. The average elapsed time between capture and boarding of the main species captured concerning the animal's condition (alive or dead). *Statistically significant $(\alpha=0.05)$. SD: standard deviation.

\begin{tabular}{lrrl}
\hline \multirow{2}{*}{ Species and species group } & \multicolumn{2}{l}{ Average time \pm SD $(\mathrm{h})$} & \multirow{2}{*}{ t- value $(P>t)$} \\
\cline { 2 - 3 } & \multicolumn{1}{c}{ alive } & \multicolumn{1}{c}{ dead } & \\
\hline Sailfish & $3 \pm 4.0$ & $11 \pm 5.9$ & $2.2446(P=0.057)$ \\
White marlin & $4 \pm 3.6$ & $11 \pm 5.0$ & $2.9109\left(P=0.007^{*}\right)$ \\
Bigeye tuna & $8 \pm 3.7$ & $10 \pm 2.9$ & $2.9019\left(P=0.005^{*}\right)$ \\
Yellowfin tuna & $8 \pm 4.1$ & $11 \pm 3.3$ & $2.7490\left(P=0.008^{*}\right)$ \\
Albacore tuna & $8 \pm 3.8$ & $11 \pm 2.9$ & $4.6719(P<0.001)$ \\
Swordfish & $6 \pm 3.6$ & $9 \pm 2.9$ & $3.1673\left(P=0.005^{*}\right)$ \\
Blue shark & $7 \pm 3.5$ & $7 \pm 3.0$ & $0.3729(P=0.716)$ \\
Other sharks & $7 \pm 3.6$ & $8 \pm 2.6$ & $0.6081(P=0.542)$ \\
Wahoo & $2 \pm 0.7$ & $10 \pm 3.9$ & $5.8474\left(P<0.001^{*}\right)$ \\
Common dolphinfish & $10 \pm 4.0$ & $10 \pm 3.0$ & $0.2255(P=0.831)$ \\
Other teleost fishes & $10 \pm 4.0$ & $10 \pm 3.5$ & $1.0131(P=0.323)$ \\
\hline
\end{tabular}

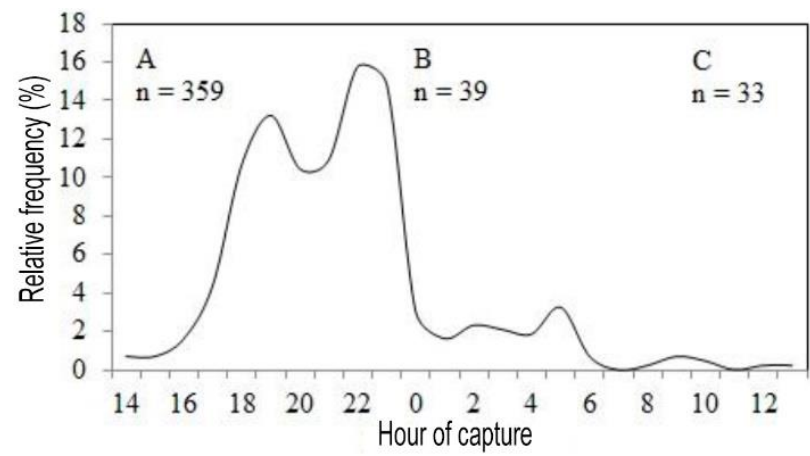

Figure 4. Distribution of hourly catches for each fishing operation. A: setting, B: drift, C: haulback.

ting that the highest rates of capture may be more closely related to the time of day than to organoleptic conditions of the bait or its movement in the water.
Bigeye tuna and yellowfin tuna, as well as blue sharks, showed an increased ability to survive the capture process for extended periods (up to $14 \mathrm{~h}$ ). Similar values were observed in longline fishing off the Reunion Islands (Poisson et al., 2010), although they were higher than those found for albacore tunas (Thunnus alalunga) in the northeast Pacific Ocean, surrounding the Hawaiian Islands (between 6-9 h) (Boggs, 1992). Additionally, carcharhinid sharks demonstrated to be resilient to the fishing gear, having endured up to 330 min (Mandelman \& Skomal, 2009) and 244 min (Brooks et al., 2012) in the hook. The results of this study suggest that the survival midpoint lies between 6 and $7 \mathrm{~h}$, as a tentative to point out an ideal soak time in the tentative to reduce mortality rates in longline fisheries (Ward et al., 2009). Boggs also reported that among the 12 most frequent taxa caught, 
$50 \%$ of the specimens were alive at the time of haulback, similarly to the value found in this study, suggesting that the release of live fish can be an effective management measure to reduce the impact of the longline fishery on the marine ecosystem.

\section{CONCLUSIONS}

The present results indicate that a significant increase in mortality of some species and taxonomically-related species groups with an increasing time elapsed between hooking and boarding. A clear trend of higher hooking rate, and possibly feeding activity, of most species and species groups, during part of the night, as well as during the setting phase (14:00-23:00 h). A higher proportion of mouth-hooked organisms, and, consequently, lower mortality rates with circle hooks compared to traditional J-hooks. An increase in posthooking/pre-boarding survival for most species and species groups associated with increased length of the specimens. We also demonstrate that a better knowledge of factors affecting the survival of pelagic fishes caught in longline fishing is important in developing and adopting fishing methods capable of reducing bycatch and target species on-hook mortality. Further, while this study used on-hook mortality as a proxy of overall fishing-induced mortality, studies have shown that post-release mortality can be significantly high.

\section{ACKNOWLEDGMENTS}

We thank the Conselho Nacional de Desenvolvimento Científico e Tecnológico $(\mathrm{CNPq})$ for financing the project (Process: 479697/2008-6) and providing the first author's scholarship, the Program of Fisheries and Aquatic Sciences, School of Forest Resources and Conservation, University of Florida, for the graduate assistantship provided to Felipe Carvalho, and the Florida Program for Shark Research for additional financial assistance. The National Oceanic and Atmospheric Administration (NOAA-Shark Population Assessment Group) donated the equipment used in the experiments. We also thank the company NorPeixe, especially fishing engineers Rivaldo Segundo (in memoriam) and Marcelo Nogueira, as well as the entire crew of the B/P MR NR for their support on conducting the experiments.

\section{REFERENCES}

Afonso, A.S., Santiago, R., Hazin, H. \& Hazin, F.H.V. 2012. Shark bycatch and mortality and hook bite-offs in pelagic longlines: interactions between hook types and leader materials. Fisheries Research, 131: 9-14.

Afonso, A.S., Hazin, F.H.V., Carvalho, F., Pacheco, J.C., Hazin, H., Kerstetter, D.W., Murie, D. \& Burgess, G.H. 2011. Fishing gear modifications to reduce elasmobranch mortality in pelagic and bottom longline fisheries off Northeast Brazil. Fisheries Research, 108: 336-343.

Amorim, A.F., Arfelli, C.A. \& Bacilier, S. 2002. Shark data from Santos longliners fishery off southern Brazil (1971-2000). Collective Volume Scientific Papers ICCAT, 54: 1341-1348.

Boggs, C.H. 1992. Depth, capture time, and hooked longevity of longline-caught pelagic fish: timing bites of fish with chips. Fishery Bulletin, 90: 643-658.

Braccini, M., Rijn, J.V. \& Frick, L. 2012. High postcapture survival for sharks, rays and chimeras discarded in the main shark fishery of Australia? PLoS ONE, https://doi.org/10.1371/journal.pone.0032547

Brooks, E.J., Mandelman, J.W., Sloman, K.A., Liss, S., Danylchuk, A.J., Cooke, S.J., Skomal, G.B., Philipp, D.P., Sims, D.W. \& Suski, C.D. 2012. The physiological response of the Caribbean reef shark (Carcharhinus perezi) to longline capture. Comparative Biochemistry and Physiology Part A: Molecular \& Integrative Physiology, 162: 94-100.

Campana, S.E., Joyce, W. \& Manning, M.J. 2009. Bycatch and discard mortality in commercially caught blue sharks Prionace glauca assessed using archival satellite pop-up tags. Marine Ecology Progress Series, 387: 241-253.

Carlson, J.K. \& Parsons, G.R. 2001. The effects of hypoxia on three sympatric shark species: physiological and behavioral responses. Environmental Biology of Fishes, 61: 427-433.

Carlson, J.K., Goldman, K.J. \& Lowe, C.G. 2004. Metabolism, energetic demand, and endothermy. In: Carrier, J.C., Musick, J.A. \& Heithaus, M.R. (Eds.). Biology of sharks and their relatives. CRC Press, Boca Raton, pp. 203-224.

Coelho, R., Infante, P. \& Santos, M.N. 2013. Application of generalized linear models and generalized estimation equations to model at-haulback mortality of blue sharks captured in a pelagic longline fishery in the Atlantic Ocean. Fisheries Research, 145: 66-75.

Cooke, S.J. \& Suski, C.D. 2004. Are circle hooks effective tools for conserving freshwater and marine recreational catch-and-release fisheries? Aquatic Conservation: Marine and Freshwater Ecosystems, 14: 299-326.

Dagorn, L., Bach, P. \& Josse, E. 2000. Movement patterns of large bigeye tuna (Thunnus obesus) in the open 
ocean, determined using ultrasonic telemetry. Marine Biology, 136: 361-371.

Davis, M. 2002. Key principles for understanding fish bycatch discard mortality. Canadian Journal of Fisheries and Aquatic Sciences, 59: 1834-1843.

Diaz, G.A. 2008. The effect of circle hooks and straight (J) hooks on the catch rates and numbers of white marlin and blue marlin released alive by the U.S. pelagic longline fleet in the Gulf of Mexico. North American Journal of Fisheries Management, 28: 500506.

Hazin, F.H.V., Hazin, H.G. \& Travassos, P. 2002. Influence of the type of longline on the catch rate and size composition of swordfish, Xiphias gladius (Linnaeus, 1758), in the southwestern equatorial Atlantic Ocean. Collective Volume Scientific Papers ICCAT, 54: 1555-1559.

Hazin, F.H.V., Zagaglia, J.R., Broadhurst, M.K., Travassos, P.E.P. \& Bezerra, T.R.Q. 1998. Review of a small-scale pelagic longline fishery off northeastern Brazil. Marine Fisheries Review, 60: 1-8.

Heisler, N. 1988. Acid-base regulation. In: Shuttleworth, T.J. (Ed.). Physiology of elasmobranch fishes. Springer-Verlag, Berlin, pp. 215-252.

Hoffmayer, E.R., Hendon, J.M. \& Parsons, G.R. 2012. Seasonal modulation in the secondary stress response of a carcharhinidae shark, Rhizoprionodon terraenovae. Comparative Biochemistry and Physiology Part A: Molecular \& Integrative Physiology, 162(2): 81-87.

Kerstetter, D.W. \& Graves, J.E. 2006. Effects of circular versus $\mathrm{J}$-style hooks on target and non-target species in a pelagic longline fishery. Fisheries Research, 80: 239-250.

Kerstetter, D.W., Pacheco, J.C., Hazin, F.H., Travassos, P.E. \& J.E. Graves. 2007. Preliminary results of circle and J-style hook comparisons in the Brazilian pelagic longline fishery. Collective Volume Scientific Papers ICCAT, 60: 2140-2147.

Lewison, R.L., Crowder, L.B., Read, A.J. \& Freeman, S.A. 2004. Understanding impacts of fisheries bycatch on marine megafauna. Trends in Ecology \& Evolution, 19: 598-604.

Malchoff, M.H \& Macneill, D.B. 1995. Guidelines to increase survival of release sport fish, Release fish survival sports fish fact sheet. Cornell Cooperative Extension, Cornell University, Ithaca.

Mandelman, J.W. \& Skomal, G.B. 2009. Diffrential sensitivity to capture stress assessed by blood acidbase status in five carcharhinid sharks. Journal of Comparative Physiology B, 179: 267-277.
Manire, C., Hueter, R., Hull, E. \& Spieler, R. 2001. Serological changes associated with gill-net capture and restraint in three species of sharks. Transactions of the American Fisheries Society, 130: 1038-1048.

Marshall, H., Field, L., Afiadata, A. Sepulveda, C., Skomal, G. \& Bernal, D. 2012. Hematological indicators of stress in longline captured sharks. Comparative Biochemistry and Physiology Part A: Molecular \& Integrative Physiology, 162: 121-129.

Milliken, H.O., Farrington, M., Carr, H.A. \& Lent, E. 1999. Survival of Atlantic cod (Gadus morhua) in the northwestern Atlantic longline fishery. Marine Technology Society Journal, 33: 19-24.

Morgan, A. \& Burgess, G.H. 2007. At-vessel fishing mortality for six species of sharks caught in the northwest Atlantic and Gulf of Mexico. Gulf and Caribbean Research, 19: 123-129.

Morgan, A. \& Carlson, J.K. 2010. Capture time, size and hooking mortality of bottom longline-caught sharks. Fisheries Research, 101(1-2): 32-37.

Moyes, C.D., Fragoso, N., Musyl, M.K. \& Brill, R. 2006. Predicting postrelease survival in large pelagic fish. Transactions of the American Fisheries Society, 135: 1389-1397.

Nielson, D.J., Waiwood, G. \& Smith, S.J. 1989. Survival of the Atlantic halibut (Hippoglossus hippoglossus) caught by longline and otter trawl gear. Canadian Journal of Fisheries and Aquatic Sciences, 46: 887897.

Pacheco, J.C., Kerstetter, D.W., Hazin, F.H., Hazin, H., Segundo, R.S.S.L., Graves, J.E., Carvalho, F. \& Travassos, P.E. 2011. A comparison of circle hook and $\mathrm{J}$ hook performance in the western equatorial Atlantic Ocean pelagic longline fishery. Fisheries Research, 107: 39-45.

Poisson, F., Gaertner, J., Durbec, J. \& Bigelow, K. 2010. Effects of lunar cycle and fishing operations on longline-caught pelagic fish: fishing performance, capture time and survival. Fishery Bulletin, 108: 268281.

R Development Core Team. 2007. R: a language and environment for statistical computing. R Foundation for Statistical Computing; Vienna, Austria.

Reinhardt, J.F., Weaver, J., Latham, P.J., Dell'Apa, A., Serafy, J.E., Browder, J.A., Christman, M., Foster, D.G. \& Blankinship, D.R. 2017. Catch rate and atvessel mortality of circle hooks versus J-hooks in pelagic longline fisheries: a global meta-analysis. Fish and Fisheries, 19: 413-430. doi: 10.1111/faf.12260

Sales, G., Giffoni, B.B., Fiedler, F.N., Azevedo, V.G., Kotas, J.E., Swimmer, Y. \& Bugoni, L. 2010. Circle hook effectiveness for the mitigation of sea turtle bycatch and capture of target species in a Brazilian 
pelagic longline fishery. Aquatic Conservation: Marine and Freshwater Ecosystems, 20: 428-436.

Serafy, J.E., Cooke, S.J., Diaz, G.A., Graves, J.E., Shivji, M.H.M. \& Swimmer, Y. 2012. Circle hooks in commercial, recreational, and artisanal fisheries: research status and needs for improved conservation and management. Bulletin of Marine Science, 88: 371391. doi: 10.5343/bms.2012.1038.

Skomal, G.B. \& Mandelman, J.W. 2012. The physiological response to anthropogenic stressors in marine elasmobranch fishes: a review with a focus on the secondary response. Comparative Biochemistry and Physiology Part A: Molecular \& Integrative Physiology, 162: 146-155.

Taylor, M.J. \& White, K.R. 1992. A meta-analysis of hooking mortality of non-anadromous trout. North American Journal of Fisheries Management, 12: 760767.

Received: 23 January 2019; Accepted: 24 July 2019
Ward, P., Epe, S., Kreutz, D., Lawrence, E., Robins, C. \& Sands, A. 2009. The effects of circle hooks on bycatch and target catch in Australia's pelagic longline fishery. Fisheries Research, 97: 253-262.

Watson, J.W., Epperly, S.P., Shah, A.K. \& Foster, D.G. 2005. Fishing methods to reduce sea turtle mortality associated with pelagic longlines. Canadian Journal of Fisheries and Aquatic Sciences, 62: 965-981.

Weng, K.C., Stokesbury, M.J.W., Boustany, A.M., Seitz, A.C., Teo, S.L.H., Miller, S.K. \& Block, B.A. 2009. Habitat and behavior of yellowfin tuna Thunnus albacares in the Gulf of Mexico determined using popup satellite archival tags. Journal of Fish Biology, 74: 1434-1449.

Yokota, K., Kiyota, M. \& Minami, H. 2006. Shark caught in a pelagic longline fishery: comparison of circle and tuna hooks. Fisheries Research, 81: 337-341. 